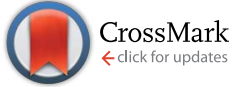

Cite this: RSC Adv., 2017, 7, 12586

Received 17th January 2017

Accepted 15th February 2017

DOI: $10.1039 / \mathrm{c} 7 \mathrm{ra00734e}$

rsc.li/rsc-advances

\section{Effect of calcination temperature on the structure and catalytic performance of copper-ceria mixed oxide catalysts in phenol hydroxylation}

\author{
Othmane Amadine, ${ }^{a}$ Younes Essamlali, ${ }^{a}$ Aziz Fihri, ${ }^{a}$ Mohamed Larzek $^{c}$ \\ and Mohamed Zahouily ${ }^{\star a b}$
}

\begin{abstract}
We report on highly active $\mathrm{CuO}\left(\mathrm{CeO}_{2}\right.$ catalysts prepared by the surfactant-template method and calcined at different temperatures. Then the obtained catalysts were characterized by means of various analytical techniques. Our findings show that the BET surface area and pore volume of the $\mathrm{CuO} @ \mathrm{aCeO}_{2}$ catalyst measured by $\mathrm{N}_{2}$ adsorption-desorption are decreasing with the elevation of calcination temperature. From the results of XRD and XPS, we determined the oxidation state of copper in the copper-ceria mixed oxide catalysts. The $\mathrm{CuO}\left(\mathrm{CeO}_{2}\right.$ catalysts displayed good catalytic activity for the phenol hydroxylation using $\mathrm{H}_{2} \mathrm{O}_{2}$ as an oxidant. Moreover, we found that the catalytic activity is improved for high calcining temperature and the optimum conditions were obtained when the catalyst $\mathrm{CuO} \cap \mathrm{CeO}_{2}$ is calcined at $800{ }^{\circ} \mathrm{C}$, which lead to higher phenol conversion of $54.62 \%$ with $92.87 \%$ of selectivity for catechol and hydroquinone. More importantly, the catalyst seems to be easily recovered by simple centrifugation. The results of catalyst recycling illustrated that the catalytic activity remained high even after five cycles with slight $\mathrm{Cu}$ leaching and slight loss of activity. Finally, a possible mechanism in phenol hydroxylation by $\mathrm{H}_{2} \mathrm{O}_{2}$ over $\mathrm{CuO}\left(\mathrm{CeO}_{2}\right.$ catalyst was also proposed.
\end{abstract}

\section{Introduction}

The degradation of phenol in wastewater using oxidation processes has attracted increasing interest compared to other traditional physico-chemical treatments such as adsorption and flocculation. The hydroxylation of phenol leads to hydroquinone (HQ) and catechol (CAT) formation, which are used as raw materials in synthesizing many valuable products namely photographic film developers, antioxidants, polymerization inhibitors, medicines, and cosmetic products. ${ }^{\mathbf{1 , 2}}$ Over the years, phenol hydroxylation has been widely investigated using classical catalysts such as soluble iron and cobalt salts in the Brichima process ${ }^{3}$ and strong homogeneous acids such as phosphoric and perchloric acids in Rhone-Poulenc process. ${ }^{4}$ However, these processes have many disadvantages regarding to solvents toxicity and catalysts recyclability as well as low yield to dihydroxybenzenes. To overcome these issues, heterogeneous catalysis was proposed to be a promising alternative. Therefore, the design of suitable heterogeneous catalysts for

${ }^{a}$ MAScIR Foundation, VARENA Center, Rabat Design, Rue Mohamed El Jazouli, Madinat El Irfane 10100-Rabat, Morocco. E-mail: m.zahouily@mascir.com

${ }^{b}$ Laboratoire de Matériaux, Catalyse et Valorisation des RessourcesNaturelles, URAC 24, Faculté des Sciences et Techniques, Université; Hassan II-Mohammedia, B.P. 146, 20650, Morocco

${ }^{c}$ Mohammed VI PolytechnicUniversity, Lot 660-Hay Moulay Rachid, 43150 Ben Guerir, Morocco hydroxylation reaction has gained interest of scientific community. Recently the hydroxylation of phenol has been developed using various heterogeneous catalysts such hydrotalcite, ${ }^{5,6}$ metallic nanoparticles,${ }^{7}$ zeolites, ${ }^{\mathbf{8}, 9}$ metal oxides ${ }^{10}$ and mesoporous materials. ${ }^{11}$ Nevertheless, some of these catalytic systems possess slow activity and low stability and require additional energy sources such as ultraviolet or visible light irradiation making this process costly. ${ }^{12-14}$ Besides, the ceria has attracted great interest in heterogeneous catalysis due to its wide accessibility, no toxicity and excellent stability. ${ }^{15-19}$ The ceria can act as catalyst by itself or as support for other active phases, due to the high oxygen mobility originating from storing and releasing $\mathrm{O}_{2}$ through the $\mathrm{Ce}^{4+} / \mathrm{Ce}^{3+}$ redox couple. ${ }^{\mathbf{2 0 , 2 1}}$ This oxide has been widely used as catalyst or support catalyst for various chemical transformations. ${ }^{15-19}$ Moreover, the catalytic activity could be significantly enhanced if other metal ions such as $\mathrm{Cu}$ ions were doped into the $\mathrm{CeO}_{2}$ because of the strong interaction of ceria with $\mathrm{Cu}$ ions. ${ }^{19}$ The $\mathrm{CuO} @ \mathrm{CeO}_{2}$ mixed oxides have become then an efficient catalyst for various reactions, such as the combustion of methane, water-gas shift, ${ }^{22}$ preferential CO oxidation, ${ }^{22}$ NO reduction. ${ }^{23}$ Actually, many investigations about the roles played by ceria and copper species in $\mathrm{CuO} @ \mathrm{CeO}_{2}$ catalysts have been extensively studied, and it was found that the active species sites for reactants as well as the roles of the $\mathrm{Cu}$ and $\mathrm{CeO}_{2}$ were distinctive in different reactions. Ce species might not be a simple spectator but rather play a direct role in the catalytic process. ${ }^{24,25}$ The ceria species 


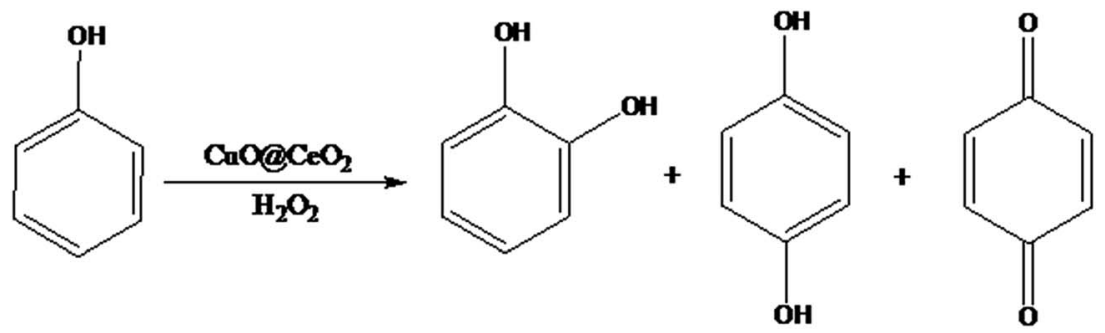

Scheme 1 Copper-ceria mixed oxide catalyzes the phenol hydroxylation.

could hinder $\mathrm{Cu}$ sintering, form strong interactions at $\mathrm{CuO}-$ $\mathrm{CeO}_{2}$ structures and enhance the thermal stability. ${ }^{26}$ In addition, many studies demonstrated that the $\mathrm{Cu}$ partly integrated into $\mathrm{CeO}_{2}$ lattice could form a $\mathrm{Cu}-\mathrm{O}-\mathrm{Ce}$ solid solution along with the formation of oxygen vacancies, which promoted the $\mathrm{Ce}^{3+} / \mathrm{Ce}^{4+}$ redox cycle and oxygen mobility. ${ }^{27}$ Keeping that in mind, the possible synergetic effects that could be a consequence of highly dispersed $\mathrm{Ce}$ and $\mathrm{Cu}$ oxides entrapped in the matrix of $\mathrm{CuO} @ \mathrm{CeO}_{2}$ structure, increasing the number of active sites leading to efficient catalytic activity for the activation of $\mathrm{H}_{2} \mathrm{O}_{2}$. In this study, we examined the synthesis and characterization of $\mathrm{CuO} @ \mathrm{CeO}_{2}$ mixed oxides and their applications as efficient reusable heterogeneous catalysts for the phenol hydroxylation in presence of $\mathrm{H}_{2} \mathrm{O}_{2}$ as an oxidant under mild reaction conditions (Scheme 1). The solid catalysts were characterized by various techniques, such as nitrogen adsorptiondesorption isotherm, scanning and transmission electronic microscopy, FTIR, XRD, and XPS. The effect of calcination temperature on the structure, composition and on the catalytic performance was investigated in this study.

\section{Experimental}

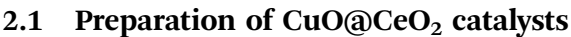

The $\mathrm{CuO} @ \mathrm{CeO}_{2}$ mixed oxides was prepared by the coprecipitation method. In typical procedure $3.1761 \mathrm{~g}$ of cetyltrimethyl ammonium bromide (CTAB) was dissolved in deionized water of $200 \mathrm{~mL}$, followed by the addition $7.5688 \mathrm{~g}$ of $\mathrm{Ce}\left(\mathrm{NO}_{3}\right)_{3} \cdot 6 \mathrm{H}_{2} \mathrm{O}$ and $1.1406 \mathrm{~g}$ of $\mathrm{Cu}\left(\mathrm{NO}_{3}\right)_{2} \cdot 3 \mathrm{H}_{2} \mathrm{O}$. Subsequently, the mixture was stirred for $30 \mathrm{~min}$, after which a solution of aqueous ammonia was added until a basic $\mathrm{pH}(\geq 11)$ under continuous stirring. The reaction took place under vigorous stirring during $4 \mathrm{~h}$, at $90^{\circ} \mathrm{C}$. The obtained solid was collected by centrifugation, and washed thoroughly with water and ethanol. The solid was dried overnight at $100{ }^{\circ} \mathrm{C}$ under vacuum then calcined at the desired temperatures for $12 \mathrm{~h}$. The copper loading on the copper-ceria mixed oxide catalysts was $4.6 \mathrm{wt} \%$.

\subsection{Characterization of $\mathrm{CuO} @ \mathrm{CeO}_{2}$}

Thermo-gravimetric analysis (TGA) was conducted under air in a TA Instrument Q500 apparatus, with a $10{ }^{\circ} \mathrm{C} \min ^{-1} \mathrm{ramp}$ between 25 and $1000{ }^{\circ} \mathrm{C}$. Fourier transform infrared (FT-IR) spectra of samples in $\mathrm{KBr}$ pellets was measured on a Bruker Vector 22 spectrometer. X-ray diffraction patterns were obtained at room temperature on a Bruker AXS D-8 diffractometer using
$\mathrm{Cu}-\mathrm{K}$ radiation in Bragg-Brentano geometry $(-2)$. TEM micrographs were obtained on a Tecnai G2 microscope at $120 \mathrm{kV}$. High-resolution transmission electron microscopy analysis was carried out on a Jeol 2100F microscope, equipped with a highresolution pole piece, field emission gun and operating at 200 $\mathrm{kV}$. The gas adsorption data was collected using a Micromeritics 3Flex Surface characterization analyzer, using $\mathrm{N}_{2}$. Prior to $\mathrm{N}_{2}$ sorption, all samples were degassed at $150{ }^{\circ} \mathrm{C}$ overnight. The specific surface areas were determined from the nitrogen adsorption/desorption isotherms (at $-196{ }^{\circ} \mathrm{C}$ ), using the BET (Brunauer-Emmett-Teller) method. Pore size distributions were calculated from the $\mathrm{N}_{2}$ adsorption isotherms with the "classic theory model" of Barrett, Joyner and Halenda (BJH) ${ }^{28}$ XPS studies were carried out in a Kratos Axis Ultra DLD spectrometer equipped with a monochromatic Al-KX-ray source (1486.6 eV) operating at $150 \mathrm{~W}$, a multi-channel plate and delay line detector under $1.0 \times 10^{-9}$ Torr vacuum. The survey and high-resolution spectra were collected at fixed analyzer pass energies of 160 and $20 \mathrm{eV}$ respectively. The instrument work function was calibrated to give an $\mathrm{Au} 4 \mathrm{f}_{7 / 2}$ metallic gold binding energy of $83.95 \mathrm{eV}$. The spectrometer dispersion was adjusted to give a binding energy of $932.63 \mathrm{eV}$ for metallic $\mathrm{Cu} 2 \mathrm{p}_{3 / 2}$. Samples were mounted in floating mode in order to avoid differential charging; charge neutralization was required for all samples. The electronic binding energy of C $1 \mathrm{~s}(284.80 \mathrm{eV})$ was used as the internal standard. The data was analyzed with commercially available software, Casa XPS. The individual peaks were fitted by a Gaussian (70\%)-Lorentzian (30\%) (GL30) function after Shirley-type background subtraction. The copper was determined by inductively coupled plasma atomic emission spectroscopy (ICP-AES) from JabinYvan.

\subsection{Hydroxylation of phenol}

The catalytic phenol hydroxylation was performed in thermostated equipped with magnetic stirrer and a reflux condenser. The reactor was charged with a mixture of $0.47 \mathrm{~g}$ of phenol, $0.05 \mathrm{~g}$ of $\mathrm{CuO} @ \mathrm{CeO}_{2}$ and $10 \mathrm{~mL}$ of deionized water. Under stirring to ensure the sufficient dispersion of the catalyst. After drop-wise addition of $\mathrm{H}_{2} \mathrm{O}_{2}$ (the molar ratio of phenol/ $\mathrm{H}_{2} \mathrm{O}_{2}$ was $3 / 1$ ), the resulting mixture was heated at $80{ }^{\circ} \mathrm{C}$ for $3 \mathrm{~h}$ under stirring. The reaction products were identified, and quantified by high-performance liquid chromatography (HPLC Shimadzu Kyoto, Japon) equipped with a reversed-phase C18 column (150 $\mathrm{mm} \mathrm{L} \times 4.6 \mathrm{~mm} \times 5 \mu \mathrm{m})$ using the methanol/water ((40/60), 
volume ratio) as the mobile phase at the flow rate of $0.5 \mathrm{~mL}$ $\min ^{-1}$ with UV detection at $190 \mathrm{~nm}$.

\section{Results and discussion}

Fig. 1 shows the TGA curve of the dried $\mathrm{CuO} @ \mathrm{CeO}_{2}$ sample prepared by the co-precipitation method (Fig. 1a). It can be seen there are two weight losses. A first weight loss centered at $50{ }^{\circ} \mathrm{C}$ relates to the loss of water molecules physisorbed on the surface of $\mathrm{CuO} @ \mathrm{CeO}_{2}$. A second large weight loss between 150 and $500{ }^{\circ} \mathrm{C}$, which can be attributed to the degradation organic molecules (Fig. 1b). Almost no weight loss and no thermal effect were observed at above $500{ }^{\circ} \mathrm{C}$, which indicates that no thermal decomposition occurs above this temperature. Hence, we decided to calcine the as prepared $\mathrm{CuO} @ \mathrm{CeO}_{2}$ samples at 400, $500,600,700$, and $800{ }^{\circ} \mathrm{C}$ for $12 \mathrm{~h}$ under flowing air.

Fig. 2 shows the XRD patterns of $\mathrm{CuO}$ (a) $\mathrm{CeO}_{2}$ catalysts calcined at different temperatures. For comparison, all the catalysts exhibited the typical patterns of cubic phase of ceria with cubic fluorite structure and the space group Fm3m (JCPDS card no. 34-0394). No crystalline phase attributed to $\mathrm{CuO}$ or $\mathrm{Cu}$ species was observed in $\mathrm{CuO} @ \mathrm{CeO}_{2}$ catalysts, probably due to the small amount of copper or the formation of a solid solution $\mathrm{Cu}-\mathrm{O}-\mathrm{Ce}$ or combination between these two phenomena. ${ }^{29,30}$ With the increment of the calcination temperature, the diffraction peaks of $\mathrm{CeO}_{2}$ phase became more narrow and intense, as a result of a characteristic change in average crystalline size. The average crystallite sizes of all the samples estimated according to Scherrer equation are given in Table 1. It is clear that the crystallite size values of the samples are found to increase from 8 to $28.7 \mathrm{~nm}$ with increasing in calcination temperatures from 400 to $800{ }^{\circ} \mathrm{C}$. This increase in crystallite size may be attributed to the Oswald ripening process assisted by the elevated temperature, this a diffusion process where the particles are getting bigger and bigger at the expense of small particles as described elsewhere. ${ }^{31}$ Compared to XRD patterns of the pure $\mathrm{CeO}_{2}$, the diffraction peaks of the $\mathrm{CuO} @ \mathrm{CeO}_{2}$ samples shifted to lower angles (inset, Fig. 2). The lattice constants of the

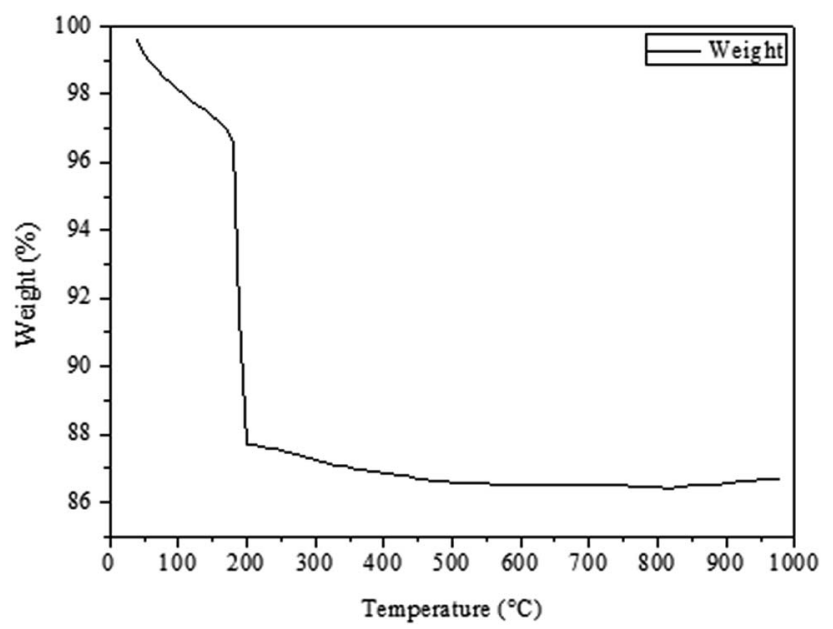

Fig. 1 TGA curve of dried $\mathrm{CuO}\left(\mathrm{CCO}_{2}\right.$ under air atmosphere.

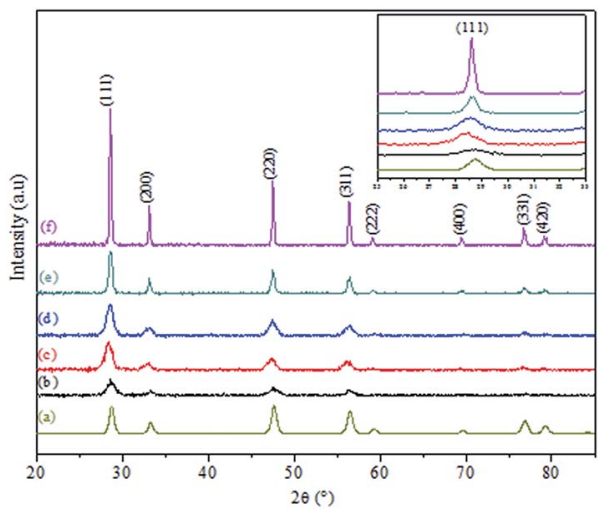

Fig. 2 XRD patterns of (a) $\mathrm{CeO}_{2}$ and $\mathrm{CuOCaCeO}$ calcined samples: (b) $400{ }^{\circ} \mathrm{C}$, (c) $500{ }^{\circ} \mathrm{C}$, (d) $600{ }^{\circ} \mathrm{C}$, (e) $700^{\circ} \mathrm{C}$ and (f) $800{ }^{\circ} \mathrm{C}$.

samples were further calculated for comparison and the results are also listed in Table 1 . It can be seen that the calculated lattice constants of all the samples were much higher than that of pure $\mathrm{CeO}_{2}(5.4043 \AA)$. The preserving of the crystallographic structure of the ceria and the increment of the lattice parameter indicating more copper species were incorporated into the $\mathrm{CeO}_{2}$ lattice and thus more amounts of oxygen vacancies were formed in the catalyst. ${ }^{32,33}$ It should be noted that the XRD patterns of the three samples calcined from 600 to $800{ }^{\circ} \mathrm{C}$ displayed a slight shift in the $\mathrm{CeO}_{2}$ diffraction peaks to higher $2 \theta$ values (Fig. 2b), which indicates the lattice expansion. The lattice parameter of $\mathrm{CeO}_{2}$ also decreased from 0.4086 to $0.4064 \mathrm{~nm}$ for the samples calcined in this temperature range. The decrease in the lattice parameter of the samples may be related to the fact that $\mathrm{Cu}^{2+}$ has been substituted into the $\mathrm{CeO}_{2}$ lattice and altered the unit cell parameter of $\mathrm{CeO}_{2}$ because of the smaller ionic radius of $\mathrm{Cu}^{2+}(0.72 \AA)$ than that of $\mathrm{Ce}^{4+}(0.97 \AA) .{ }^{34,35}$

Fig. 3 shows FTIR spectra in the $400-4000 \mathrm{~cm}^{-1}$ range of $\mathrm{CuO} @ \mathrm{CeO}_{2}$ before and after thermal treatment at different temperatures ranging from $400-800{ }^{\circ} \mathrm{C}$. The five spectra show a group of strong intense bands at 3360 and $1630 \mathrm{~cm}^{-1}$ which may be attributed to the $-\mathrm{OH}$ stretching vibration and to the $\mathrm{H}_{2} \mathrm{O}$ bending vibration, respectively. ${ }^{36,37}$ The band centered at $1479 \mathrm{~cm}^{-1}$ can be attributed to the $\mathrm{CH}_{3}$ organic group derived from the CTAB surfactant. The fingerprint of ceria is assigned in FTIR spectroscopy to the Ce-O-Ce stretching vibration, which is detected toward $400 \mathrm{~cm}^{-1} .^{38,39}$ Indeed, that all spectra are similar in the existence of the characteristic band, indicating that the base framework of the structure does not change when ceria is loaded with copper species. Finally, all absorption bands corresponding to vibrations of water molecules adsorbed (3360 and $1630 \mathrm{~cm}^{-1}$ ) and residual nitrate in $1303 \mathrm{~cm}^{-1}$, disappeared after calcination at $700{ }^{\circ} \mathrm{C}$, which indicates that the organic component has been removed from the $\mathrm{CuO} @ \mathrm{CeO}_{2}$ sample.

To investigate chemical states and the compositions in the content on the surface of the $\mathrm{CuO} @ \mathrm{CeO}_{2}$ calcined at different temperatures, the XPS measurements were carried out and the XPS spectra of Ce 3d, Cu 2P, and O 1s were obtained, as shown in Fig. 4. The relative concentration of different oxidation states 
Table 1 Lattice parameter, crystallite size, nanoparticles diameter, BET surface area and pore volume of $\mathrm{CuOCCeO}_{2}$ serial catalysts

\begin{tabular}{|c|c|c|c|c|c|c|}
\hline Samples & $\begin{array}{l}\text { Cell parameter } \\
(\AA)\end{array}$ & $\begin{array}{l}\text { Crystallite size } \\
\text { (nm) }\end{array}$ & $\begin{array}{l}\text { Particles size } \\
(\mathrm{nm})\end{array}$ & $\begin{array}{l}\text { Surface area } \\
\left(\mathrm{m}^{2} \mathrm{~g}^{-1}\right)\end{array}$ & $\begin{array}{l}\text { Pore volume } \\
\left(\mathrm{cm}^{3} \mathrm{~g}^{-1}\right)\end{array}$ & $\begin{array}{l}\text { Pore diameter } \\
(\mathrm{nm})\end{array}$ \\
\hline $\mathrm{CeO}_{2}$ & 5.4043 & 6.5 & - & 132 & 0.4834 & 11.5 \\
\hline $\mathrm{CuO} @ \mathrm{CeO}_{2}-500{ }^{\circ} \mathrm{C}$ & 5.4091 & 9 & 8.9 & 153 & 0.4231 & 12.59 \\
\hline $\mathrm{CuO} @ \mathrm{CeO}_{2}-600{ }^{\circ} \mathrm{C}$ & 5.4086 & 9.5 & 9.4 & 136 & 0.3354 & 12.49 \\
\hline $\mathrm{CuO} @ \mathrm{CeO}_{2}-700{ }^{\circ} \mathrm{C}$ & 5.4068 & 21.2 & 19.2 & 32 & 0.1085 & 9.87 \\
\hline
\end{tabular}

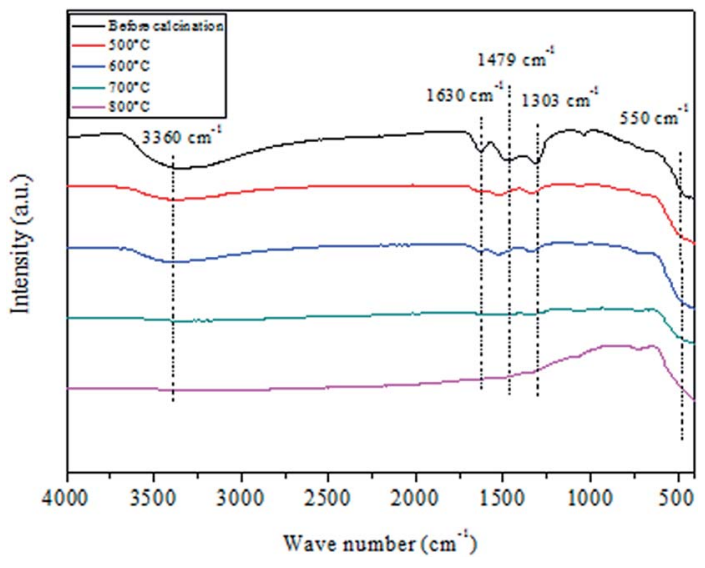

Fig. 3 FT-IR spectra of $\mathrm{CuOCCeO}$ calcined samples.

of Ce, $\mathrm{Cu}$ and $\mathrm{O}$ are summarized in Table 2. As shown in Fig. 4a the Ce 3d XPS spectra indicated the existence of two oxidation states of cerium $\mathrm{Ce}^{4+}$ and $\mathrm{Ce}^{3+}$. The main peaks located at 917.2 $\left(\mathrm{u}^{\prime \prime \prime}\right)$ and $898 \mathrm{eV}\left(\mathrm{v}^{\prime \prime \prime}\right)$ are associated with the final state of the $3 \mathrm{~d}^{10} 4 \mathrm{f}^{0}$ configuration of $\mathrm{Ce}^{4+}$ ions. ${ }^{40}$ While, the peaks located at $904.1\left(\mathrm{u}^{\prime}\right)$ and $885.5 \mathrm{eV}\left(\mathrm{v}^{\prime}\right)$ corresponding to the initial electronic state $3 \mathrm{~d}^{10} 4 \mathrm{~F}^{1}$ of $\mathrm{Ce}^{3+}$ ions. ${ }^{41}$ The corresponding $\mathrm{Cu} 2 \mathrm{p}$ XPS spectra for all of the $\mathrm{CuO} @ \mathrm{CeO}_{2}$ samples are shown in Fig. $4 \mathrm{~b}$. Based on the peak-fitting deconvolution of the main peak of the $\mathrm{Cu} 2 \mathrm{p}_{3 / 2}$ we note the existence of a peak at $933.5 \mathrm{eV}$ characteristic of divalent cations $\mathrm{Cu}^{2+}$ in all of the samples. In addition, we observed the appearance of a peak located at $932.5 \mathrm{eV}$ for the sample calcined at a temperature above $600{ }^{\circ} \mathrm{C}$. This peak could be attributed to the reduction of $\mathrm{Cu}^{2+}$ to $\mathrm{Cu}^{+}$. The formation of this species is favored by the presence of $\mathrm{Ce}^{3+}$, which facilitating the redox equilibrium $\left(\mathrm{Ce}^{3+}+\mathrm{Cu}^{2+} \leftrightarrow \mathrm{Ce}^{4+}+\mathrm{Cu}^{+}\right) .{ }^{42}$ Indeed, the

Table 2 Surface composition of samples determined by XPS

\begin{tabular}{|c|c|c|c|c|}
\hline \multirow[b]{2}{*}{ Samples } & \multicolumn{4}{|c|}{ Surface element (\%) } \\
\hline & $\mathrm{Ce}^{3+}$ & $\mathrm{Ce}^{4+}$ & $\mathrm{Cu}^{2+}$ & $\mathrm{Cu}^{+}$ \\
\hline $\mathrm{CuO} @ \mathrm{CeO}_{2}-400{ }^{\circ} \mathrm{C}$ & 25 & 75 & 100 & - \\
\hline 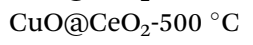 & 20 & 80 & 100 & - \\
\hline $\mathrm{CuO} @ \mathrm{CeO}_{2}-600{ }^{\circ} \mathrm{C}$ & 20 & 80 & 50.28 & 49.72 \\
\hline $\mathrm{CuO} @ \mathrm{CeO}_{2}-700{ }^{\circ} \mathrm{C}$ & 25 & 75 & 48.57 & 51.43 \\
\hline $\mathrm{CuO} @ \mathrm{CeO}_{2}-800{ }^{\circ} \mathrm{C}$ & 20 & 80 & 62.71 & 37.29 \\
\hline
\end{tabular}
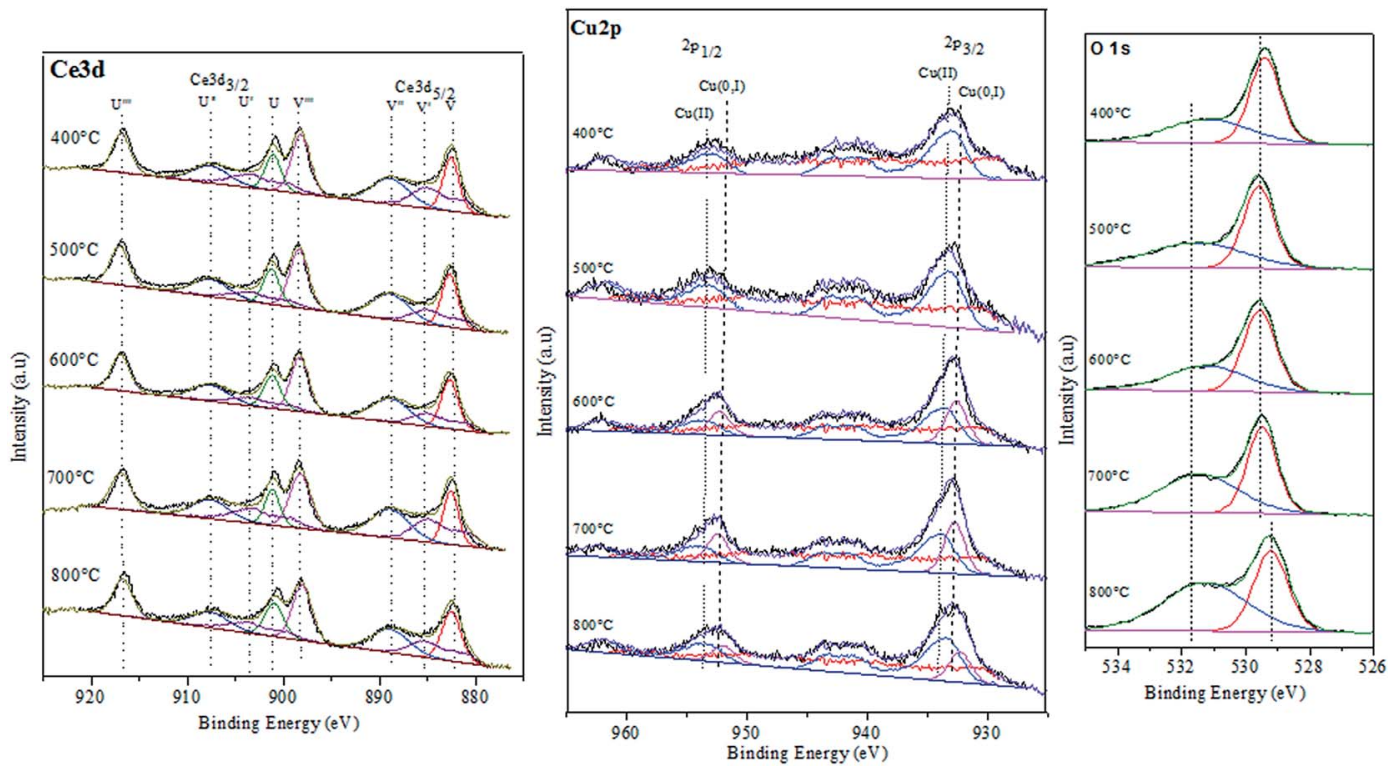

Fig. 4 XPS spectra of $\mathrm{CuO} \mathrm{aCeO}_{2}$ calcined samples. 
reduction of $\mathrm{Cu}^{2+}$ to $\mathrm{Cu}^{+}$indicating the presence of a strong interaction between $\mathrm{Cu}$ clusters and $\mathrm{CeO}_{2} \cdot{ }^{43}$ The fitting procedures of the $\mathrm{O} 1 \mathrm{~s}$ of the $\mathrm{CuO} @ \mathrm{CeO}_{2}$ samples are shown in Fig. 4c. The $\mathrm{O} 1 \mathrm{~s}$ spectrum reveals the presence of two peaks, which the first peak located between 529 and $530 \mathrm{eV}$ is generally characteristic of the lattice oxygen forming the fluorite structure with cerium. While the second peak at about $531.5 \mathrm{eV}$ can be attributed to the chemisorbed oxygen by the material as the carbonate or hydroxyl groups. ${ }^{44}$ Moreover, we observed that there is a slight shift of the peaks characteristic of oxygen structure of $\mathrm{CuO} @ \mathrm{CeO}_{2}$ towards lower energies when the temperature calcination increase from 400 to $800{ }^{\circ} \mathrm{C}$, which indicates the appearance of a new chemical environment for oxygen. The formation of this $\mathrm{Ce}-\mathrm{O}-\mathrm{Cu}$ can be responsible for the observed shift. ${ }^{45}$

The morphology of the surface of $\mathrm{CuO} @ \mathrm{CeO}_{2}$ calcined at different temperatures was investigated by SEM. As shown in Fig. 5, homogeneous microstructures were observed for all the materials consisting of crystallites having various size and forms with an irregular surface roughness. Additionally, the calcination temperature didn't clearly influence on the morphology of $\mathrm{CuO} @ \mathrm{CeO}_{2}$ samples.

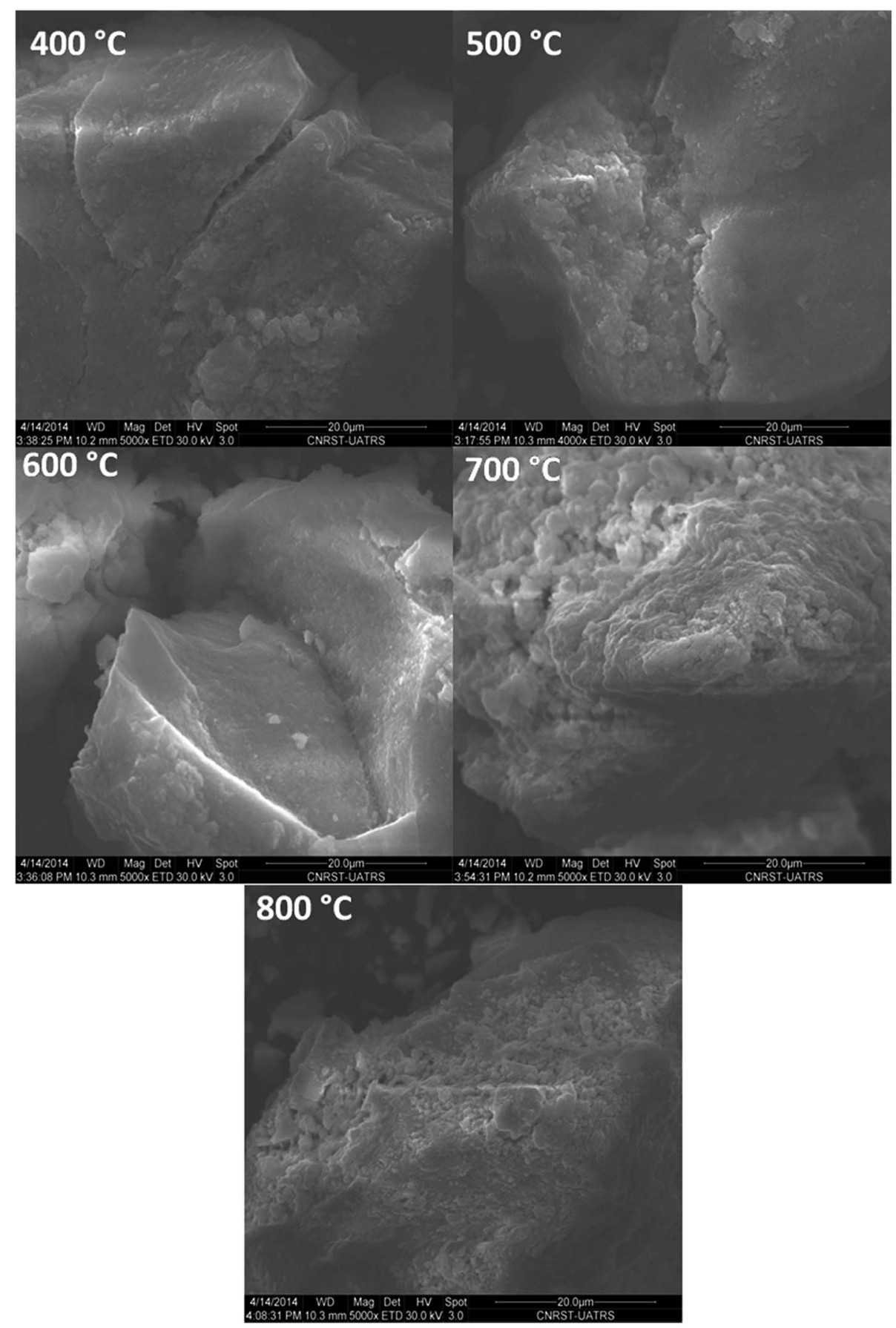

Fig. 5 SEM micrographs of $\mathrm{CuO} \mathrm{aCeO}_{2}$ calcined samples. 
The typical TEM images of the prepared $\mathrm{CuO} @ \mathrm{CeO}_{2}$ at different calcination temperatures and the particles sizes of all the samples calculated by TEM are given in Fig. 6a-m and Table

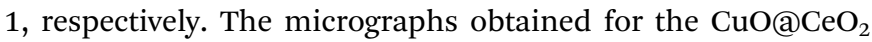
samples calcined at 400 and $500{ }^{\circ} \mathrm{C}$ show well-dispersed particles where smaller particle sizes can be observed ranging from 6.7 to $26 \mathrm{~nm}$. However, the particle size of $\mathrm{CuO} @ \mathrm{CeO}_{2}$ increased significantly with increasing the calcination temperature from 500 to $800{ }^{\circ} \mathrm{C}$. When calcination temperature rose to $800{ }^{\circ} \mathrm{C}$ (Fig. 6m), the $\mathrm{CuO} @ \mathrm{CeO}_{2}$ particles seem to be agglomerated and forming heterogeneous aggregates of nanoparticles and the mean particle diameter increased from 6.7 to $26 \mathrm{~nm}$. This observation can be explained by the Ostwald ripening process where small nanoparticles merge to form large nanoparticles. This above finding indicated that the particle size was dependent on calcination temperature, which was also in agreement with the result of XRD pattern.

The HR-TEM technique was also used in order to analyze mostly the local structure and the inter-planar distances of the $\mathrm{CuO} @ \mathrm{CeO}_{2}$ calcined at a different temperature. The images (b)-(n) in Fig. 6 show the representative HR-TEM images of $\mathrm{CuO} @ \mathrm{CeO}_{2}$. These images show the arrangement of nanoparticles in this structure, which is characterized by its special egg or ellipsoid shape. The lattice spacing was determined to be $0.31 \mathrm{~nm}$ which correspond to the lattice $d(111)$ interplant spacing of the fluorite structure of ceria. These analyses corroborate what is observed by the SEAD (Fig. 6c-o).

Fig. 7a shows the isotherms for the $\mathrm{CuO} @ \mathrm{CeO}_{2}$ samples calcined in the temperature range of 400 to $800{ }^{\circ} \mathrm{C}$. The $\mathrm{N}_{2}$

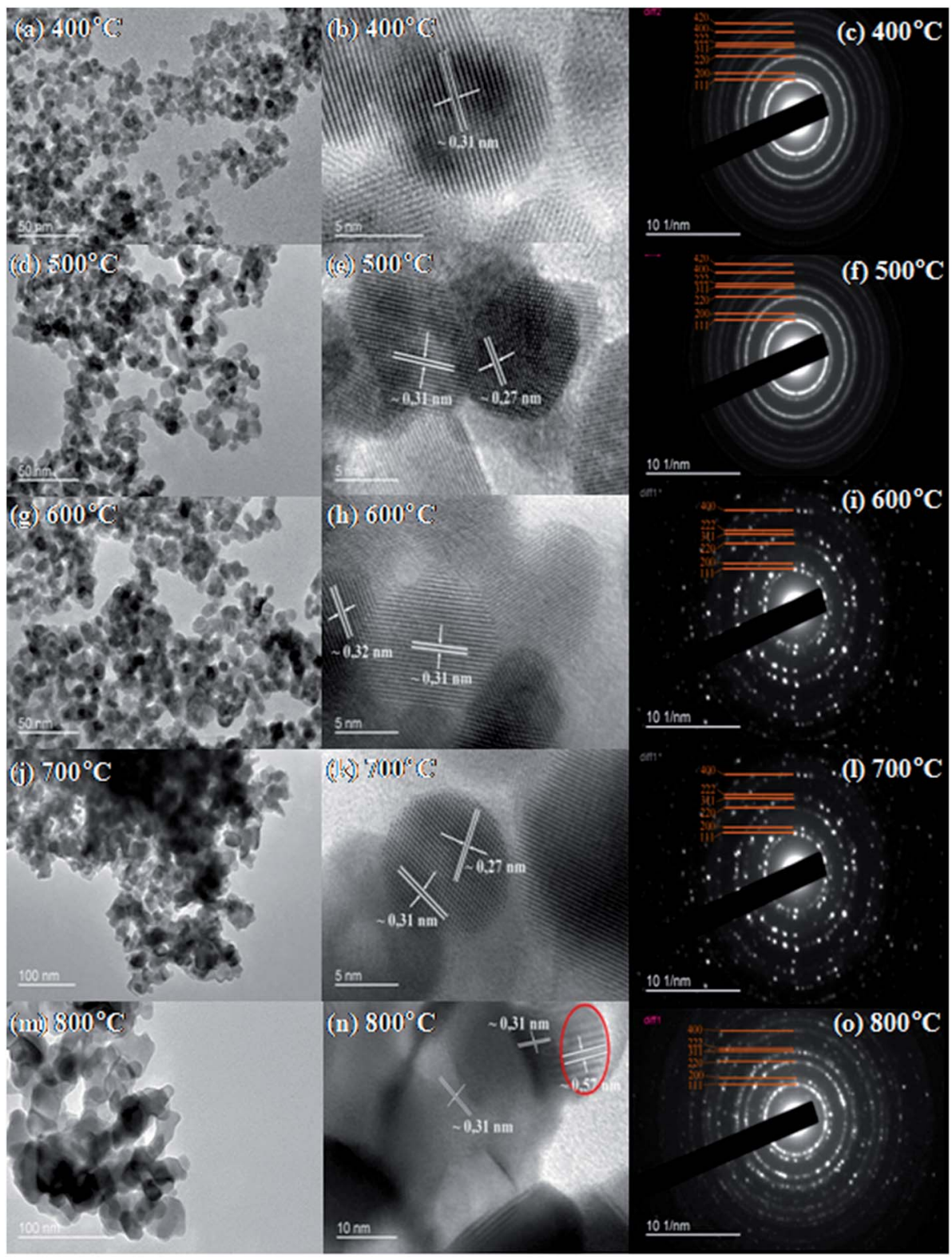

Fig. 6 Representative TEM (a-m), HRTEM (b-n) images and SAED (c-o) pattern of calcined $\mathrm{CuO}\left(\mathrm{aCeO} \mathrm{C}_{2}\right.$ samples. 

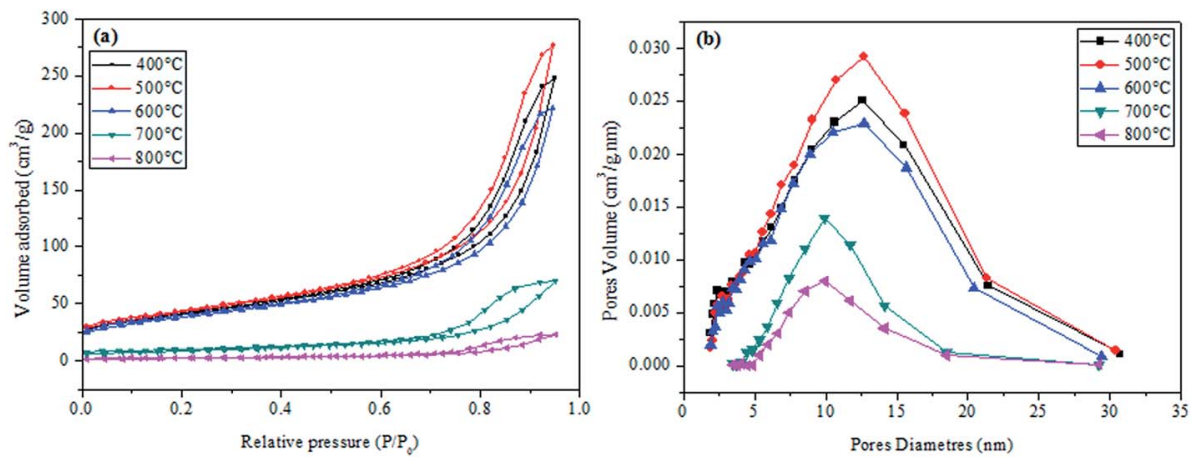

Fig. 7 Nitrogen adsorption/desorption isotherms of calcined $\mathrm{CuO}\left(\mathrm{CeO}_{2}\right.$ samples (a), and $\mathrm{BJH}$ pore size distribution (b).

adsorption-desorption isotherms of $\mathrm{CuO} @ \mathrm{CeO}_{2}$ are assigned to type IV isotherms with the $\mathrm{H} 4$ type of hysteresis according to IUPAC classification, ${ }^{46,47}$ which characteristic of a material mesoporous. In addition, we observed that there is a decrease in the volume of nitrogen adsorbed with increasing calcination temperature, which leads to a reduction in the BET surface area. The BET surface area, pore volume and pore diameter of the $\mathrm{CuO} @ \mathrm{CeO}_{2}$ samples calcined at different temperatures are summarized in Table 1. It can be seen that there is a continuous increase in the BET surface area and the pore volume from 144 to $153 \mathrm{~m}^{2} \mathrm{~g}^{-1}$ and 0.3778 to $0.4231 \mathrm{~cm}^{3} \mathrm{~g}^{-1}$ with increasing the calcination temperature from 400 to $500{ }^{\circ} \mathrm{C}$ respectively, which can be explained by the elimination of organic matter in our samples. However, when the temperature increase from 500 to $800{ }^{\circ} \mathrm{C}$ the surface area and pore volume decrease from 153 to 8 $\mathrm{m}^{2} \mathrm{~g}^{-1}$ and 0.4231 to $0.0998 \mathrm{~cm}^{3} \mathrm{~g}^{-1}$ respectively. The subsequent decline in the surface area upon thermal treatment at a higher temperature could be due to the increase in particle size and the degree of agglomeration of $\mathrm{CuO} @ \mathrm{CeO}_{2}$ samples under an effect of temperature. Indeed, the corresponding pore size distribution of $\mathrm{CuO} @ \mathrm{CeO}_{2}$ calcined at different temperatures was calculated by the $\mathrm{BJH}$ method and was plotted in Fig. 8b. The materials presented mesopores width distribution in the range between 12.63 and $9.69 \mathrm{~nm}$. Furthermore, the pore size distribution of $\mathrm{CuO} @ \mathrm{CeO}_{2}$ shows an increase from 12.59 to $12.63 \mathrm{~nm}$ during the calcination of $\mathrm{CuO} @ \mathrm{CeO}_{2}$ at $500{ }^{\circ} \mathrm{C}$. When the calcined temperature increased from 500 to $800{ }^{\circ} \mathrm{C}$, the pore size distribution of $\mathrm{CuO} @ \mathrm{CeO}_{2}$ decreased from 12.63 to $9.69 \mathrm{~nm}$. These results can be due to the particle agglomeration, which leads to sintering to form pores of smaller sizes.

$\mathrm{CuO} @ \mathrm{CeO}_{2}$ samples were evaluated as heterogeneous catalysts for the phenol hydroxylation with aqueous hydrogen peroxide as oxidant. Phenol conversion and selectivity of catechol and hydroquinone are summarized in Table 3. Initially, the reaction conducted without a catalyst and no activity was observed despite a prolonged reaction time (Table 3 , entry 1 ). It can be seen that the phenol conversion is very low when $\mathrm{CeO}_{2}$

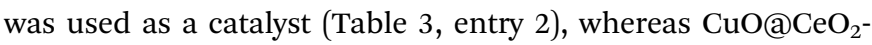
$400{ }^{\circ} \mathrm{C}$ exhibited high catalytic activity for phenol hydroxylation under the same conditions, indicating that the phenol hydroxylation is very sensitive to the presence of copper species (Table 3 , entry 3). Subsequently, the influence of the calcination temperatures of the $\mathrm{CuO} @ \mathrm{CeO}_{2}$ on their catalytic activities was examined. Thus, we tested the reaction with $\mathrm{CuO} @ \mathrm{CeO}_{2}$ catalyst calcined at different temperatures namely $\mathrm{CuO} @ \mathrm{CeO}_{2}$ $500{ }^{\circ} \mathrm{C}, \mathrm{CuO} @ \mathrm{CeO}_{2}-600{ }^{\circ} \mathrm{C}, \mathrm{CuO} @ \mathrm{CeO}_{2}-700{ }^{\circ} \mathrm{C}$ and $\mathrm{CuO} @ \mathrm{CeO}_{2}-$ $800{ }^{\circ} \mathrm{C}$. According our experimental findings, we observed that the phenol conversion increased from 26.74 to $53.4 \%$ with the elevation of calcination temperature of $\mathrm{CuO} @ \mathrm{CeO}_{2}$ from 400 to $800{ }^{\circ} \mathrm{C}$, respectively (Table 3 , entries 3 and 7). Indeed, we can

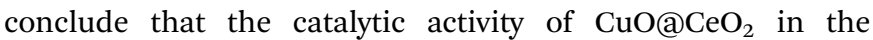
hydroxylation of phenol reaction was not directly related to the surface area of $\mathrm{CuO} @ \mathrm{CeO}_{2}$, which decrease from 144 to $8 \mathrm{~m}^{2}$ $\mathrm{g}^{-1}$ for the catalyst $\mathrm{CuO} @ \mathrm{CeO}_{2}$ calcined at 400 and $800{ }^{\circ} \mathrm{C}$, respectively. Therefore, we can conclude that the catalytic activity of $\mathrm{CuO} @ \mathrm{CeO}_{2}$ may be related to other parameters that play a role in monitoring the performance of this catalyst, such as the electronic exchange between the two redox pairs $\mathrm{Cu}^{+} / \mathrm{Cu}^{2+}$ and $\mathrm{Ce}^{3+} / \mathrm{Ce}^{4+}$ revealed by XPS and the presence of oxygen vacancies, which can be beneficial to high activity of $\mathrm{CuO} @ \mathrm{CeO}_{2}$ catalyst calcined at high temperature. ${ }^{48-50}$ It should be noted the phenol hydroxylation was also investigated using $\mathrm{CuO} @ \mathrm{CeO}_{2}$ catalyst prepared by co-precipitation without surfactant and calcined at $800{ }^{\circ} \mathrm{C}$. However, under same conditions, the latter exhibited significantly lower catalytic activity since only $31 \%$ of phenol conversion was observed.

The effects of the following reaction parameters: duration, reaction temperature, solvents and molar ratios of reactants on

Table 3 The results of phenol hydroxylation over calcined $\mathrm{CuOaCeO}$ catalysts $^{a}$

\begin{tabular}{|c|c|c|c|c|c|}
\hline \multirow[b]{2}{*}{ Entry } & \multirow[b]{2}{*}{ Catalyst } & \multirow{2}{*}{$\begin{array}{l}\text { Conversion } \\
(\%)\end{array}$} & \multicolumn{3}{|c|}{ Selectivity (\%) } \\
\hline & & & CAT & HQ & BQ \\
\hline 1 & Without & n.r. & - & - & - \\
\hline 2 & $\mathrm{CeO}_{2}$ & 2.32 & 70.12 & 25.21 & 4.67 \\
\hline 3 & $\mathrm{CuO} @ \mathrm{CeO}_{2}-400{ }^{\circ} \mathrm{C}$ & 26.74 & 39.63 & 32.73 & 10.62 \\
\hline 4 & $\mathrm{CuO} @ \mathrm{CeO}_{2}-500{ }^{\circ} \mathrm{C}$ & 27.59 & 44.78 & 48.2 & 7.01 \\
\hline 5 & $\mathrm{CuO} @ \mathrm{CeO}_{2}-600{ }^{\circ} \mathrm{C}$ & 30.08 & 51.85 & 32.86 & 7.22 \\
\hline 6 & $\mathrm{CuO} @ \mathrm{CeO}_{2}-700{ }^{\circ} \mathrm{C}$ & 46.62 & 54.24 & 26.68 & 6.06 \\
\hline 7 & $\mathrm{CuO} @ \mathrm{CeO}_{2}-800{ }^{\circ} \mathrm{C}$ & 53.40 & 61.86 & 32.43 & 5.71 \\
\hline
\end{tabular}

${ }^{a}$ Reaction conditions: phenol, $5 \mathrm{mmol} ; \mathrm{H}_{2} \mathrm{O}_{2}, 5 \mathrm{mmol}$; catalyst, $50 \mathrm{mg}$; water, $10 \mathrm{~mL}$; time, $6 \mathrm{~h} ; 80{ }^{\circ} \mathrm{C}$. 


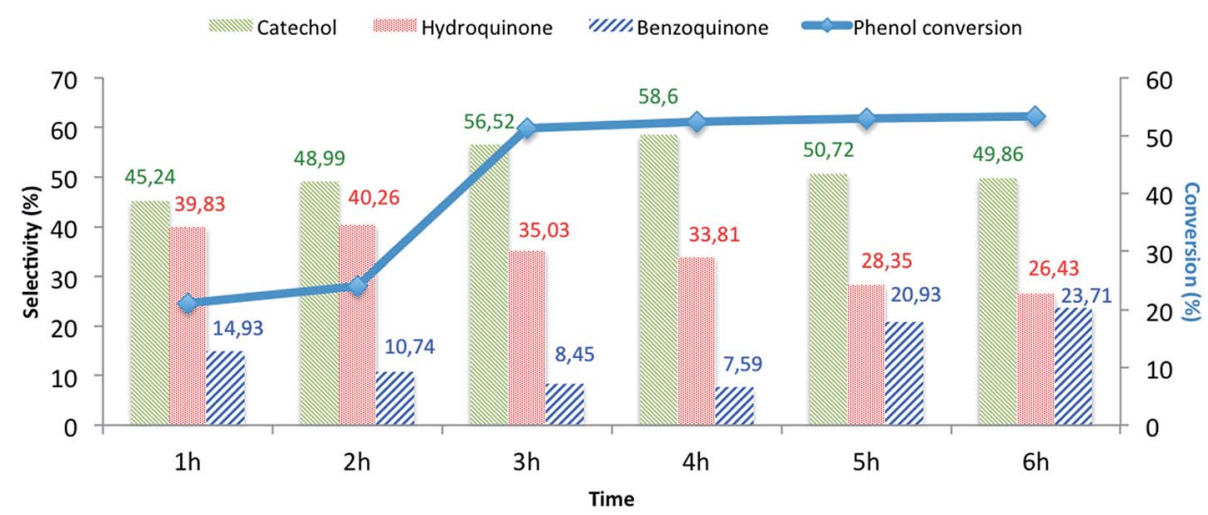

Fig. 8 The influence of the reaction time on the phenol hydroxylation over $\mathrm{CuO}\left(\mathrm{CeO}_{2}-800{ }^{\circ} \mathrm{C}^{a}\right.$. ${ }^{a}$ Reaction conditions: phenol, $5 \mathrm{mmol}$; $\mathrm{H}_{2} \mathrm{O}_{2}$, $5 \mathrm{mmol}$; catalyst, $50 \mathrm{mg}$; water, $10 \mathrm{~mL}$; time, $3 \mathrm{~h} ; 80{ }^{\circ} \mathrm{C}$.

phenol hydroxylation in the presence of $\mathrm{CuO} @ \mathrm{CeO}_{2}-800{ }^{\circ} \mathrm{C}$ catalyst were investigated. First, the effect of reaction time on conversion of phenol over $\mathrm{CuO} @ \mathrm{CeO}_{2}-800{ }^{\circ} \mathrm{C}$ was studied and the results are presented in Fig. 8. It is worth mentioning that increasing the reaction time led to an increase in phenol hydroxylation reaching its highest level of $54.62 \%$ after 3 hours. Besides, the selectivity of the reaction for the dihydroxybenzene was observed to decrease with increasing time. This may be attributed to the oxidation of dihydroxybenzene to benzoquinone and subsequently to tar formation..$^{51}$ This shows clearly that further increase of the reaction time won't be beneficial for this reaction.

The effect of reaction temperature was investigated from 50 to $100{ }^{\circ} \mathrm{C}$ to avoid decomposition $\mathrm{H}_{2} \mathrm{O}_{2}$ at high temperature and to prevent further oxidation of formed dihydroxybenzene to benzoquinone $\mathrm{e}^{52}$ and the results are presented in Table 4 . Based on the results obtained, the phenol conversion and selectivity for dihydroxybenzene increased with increasing temperature. These results could be explained by the high concentrations of free radicals formed at high temperature. At $80{ }^{\circ} \mathrm{C}$, the phenol conversion reached a maximum of $54.62 \%$.

The effect of the phenol/ $\mathrm{H}_{2} \mathrm{O}_{2}$ molar ratios on the phenol hydroxylation was studied and the experimental findings are presented in Table 5. When decreasing the phenol $/ \mathrm{H}_{2} \mathrm{O}_{2}$ molar from 3 to 0.5 , the conversion of phenol and the selectivity for the

Table 4 The influence of temperature on the phenol hydroxylation over $\mathrm{CuOCCeO}-800^{\circ} \mathrm{C}^{a}$

\begin{tabular}{lllllr}
\hline & \multirow{2}{*}{$\begin{array}{l}\text { Temperature } \\
\text { Entry }\end{array}$} & $\begin{array}{l}\text { Conversion } \\
(\%)\end{array}$ & \multicolumn{3}{l}{ Selectivity (\%) } \\
\cline { 5 - 6 } & $(\%)$ & CAT & HQ & BQ \\
\hline 1 & 50 & 20.10 & 55.24 & 34.48 & 10.27 \\
2 & 60 & 34.12 & 58.27 & 33.99 & 7.73 \\
3 & 70 & 41.54 & 60.14 & 33.29 & 6.57 \\
4 & 80 & 54.62 & 61.86 & 32.43 & 5.71 \\
5 & 90 & 54.50 & 62.65 & 31.96 & 5.39 \\
6 & 100 & 55.06 & 60.50 & 33.02 & 6.48
\end{tabular}

${ }^{a}$ Reaction conditions: phenol, $5 \mathrm{mmol} ; \mathrm{H}_{2} \mathrm{O}_{2}, 5 \mathrm{mmol}$; catalyst, $50 \mathrm{mg}$; water, $10 \mathrm{~mL}$; time, $3 \mathrm{~h}$. dihydroxybenzene increased significantly. However, the addition of more hydrogen peroxide in presence of $\mathrm{CuO} @ \mathrm{CeO}_{2}-800{ }^{\circ} \mathrm{C}$ is undesirable due to the oxidation reaction of dihydroxybenzene. ${ }^{53}$

The influence of the solvent nature on the phenol hydroxylation was also investigated and the experimental findings are summarized in Table 6. It can be observed that when the reaction was performed in water, the reaction showed much higher conversion, but when the methanol and ethanol were used as solvents, the catalytic reaction gave low conversion. The difference in catalytic activity may be due to the high solubility of the phenol and $\mathrm{H}_{2} \mathrm{O}_{2}$ in water and the stability of the free radicals ${ }^{\circ} \mathrm{OH}$ in water compared to other organic solvents. ${ }^{5,54}$ Obviously, water is favorable for improving phenol conversion as well as obtaining good product selectivity.

Table 5 The influence of the molar ratio of reactants on the phenol hydroxylation over $\mathrm{CuO} \mathrm{aCeO}_{2}-800{ }^{\circ} \mathrm{C}^{a}$

\begin{tabular}{llllll}
\hline & & & \multicolumn{3}{l}{ Selectivity $(\%)$} \\
\cline { 5 - 6 } Entry & $\begin{array}{l}\text { Molar ratio } \\
\left(\mathrm{PhOH}: \mathrm{H}_{2} \mathrm{O}_{2}\right)\end{array}$ & $\begin{array}{l}\text { Conversion } \\
(\%)\end{array}$ & CAT & HQ & BQ \\
\hline 1 & $1: 4$ & 53.3 & 54.15 & 25.15 & 20.7 \\
2 & $1: 2$ & 54.62 & 57.11 & 35.79 & 7.10 \\
3 & $1: 1$ & 53.27 & 56.52 & 35.03 & 8.45 \\
4 & $2: 1$ & 51.27 & 54.52 & 38.03 & 7.45 \\
5 & $3: 1$ & 36.21 & 78.24 & 13.49 & 8.25
\end{tabular}

${ }^{a}$ Reaction conditions: sample of phenol reacted with $\mathrm{H}_{2} \mathrm{O}_{2}$ in different molar ratios over $50 \mathrm{mg}$ of $\mathrm{CuO}$ @ $\mathrm{CeO}_{2}$ in $10 \mathrm{~mL}$ of water at $30^{\circ} \mathrm{C}$ for $3 \mathrm{~h}$.

Table 6 Effect of solvents on the phenol hydroxylation over $\mathrm{CuO} @ \mathrm{CeO}_{2}-800{ }^{\circ} \mathrm{C}^{a}$

\begin{tabular}{llllll}
\hline & & & \multicolumn{3}{l}{ Selectivity (\%) } \\
\cline { 5 - 6 } Entry & Solvent & Conversion (\%) & CAT & HQ & BQ \\
\hline 1 & $\mathrm{H}_{2} \mathrm{O}$ & 54.62 & 56.68 & 35.03 & 8.45 \\
2 & $\mathrm{MeOH}$ & 28.24 & 9 & - & 91 \\
3 & $\mathrm{EtOH}$ & 15.64 & 7 & - & 93
\end{tabular}

${ }^{a}$ Reaction conditions: phenol, $5 \mathrm{mmol} ; \mathrm{H}_{2} \mathrm{O}_{2}, 5 \mathrm{mmol}$; catalyst, $50 \mathrm{mg}$; time, $3 \mathrm{~h} ; 80^{\circ} \mathrm{C}$. 
Table 7 The influence of the catalyst content on the phenol hydroxylation over $\mathrm{CuOaCeO}-800^{\circ} \mathrm{C}^{a}$

\begin{tabular}{|c|c|c|c|c|c|}
\hline \multirow[b]{2}{*}{ Entry } & \multirow{2}{*}{$\begin{array}{l}\text { Catalytic amount } \\
(\mathrm{mg})\end{array}$} & \multirow{2}{*}{$\begin{array}{l}\text { Conversion } \\
(\%)\end{array}$} & \multicolumn{3}{|c|}{ Selectivity (\%) } \\
\hline & & & CAT & HQ & BQ \\
\hline 1 & 20 & 17.3 & 58.04 & 30.15 & 11.81 \\
\hline 2 & 40 & 53.27 & 56.52 & 35.03 & 8.45 \\
\hline 3 & 50 & 54.62 & 58.68 & 34.19 & 7.13 \\
\hline 4 & 60 & 56.71 & 63.31 & 31.52 & 5.16 \\
\hline
\end{tabular}

${ }^{a}$ Reaction conditions: phenol, $5 \mathrm{mmol} ; \mathrm{H}_{2} \mathrm{O}_{2}, 5 \mathrm{mmol}$; water, $10 \mathrm{~mL}$; time, $3 \mathrm{~h} ; 80^{\circ} \mathrm{C}$.

The studies on the influence of the catalyst content on the phenol hydroxylation process were also investigated and the obtained findings are presented in Table 7. It was observed that the phenol conversion increased from 17.3 to $53.27 \%$ with increasing the content of the catalyst in the reaction mixture from 20 to $40 \mathrm{mg}$. The further increment of catalyst amount to $50 \mathrm{mg}$ resulted in only a negligible increase in phenol conversion. It was believed that a large number of copper active sites increased the decomposition rate of $\mathrm{H}_{2} \mathrm{O}_{2}$, resulting in the decrease of $\mathrm{H}_{2} \mathrm{O}_{2}$ efficiency. ${ }^{55,56}$

Therefore, the possible reaction mechanism in the presence of $\mathrm{CuO} @ \mathrm{CeO}_{2}-800{ }^{\circ} \mathrm{C}$ is illustrated in Scheme 2. The $\mathrm{Ce}^{3+}-\bullet-$ $\mathrm{Cu}^{+}$species are catalytically active centers for the phenol hydroxylation with $\mathrm{H}_{2} \mathrm{O}_{2}$ being used as the oxidizing agent. The ' $\mathrm{OH}$ radicals were generated $v i a$ the decomposition of $\mathrm{H}_{2} \mathrm{O}_{2}$ over $\mathrm{Ce}^{3+}-\odot-\mathrm{Cu}^{+}$due to the existence of $\mathrm{Ce}^{3+} / \mathrm{Ce}^{4+}$ (Scheme 2B). The $\mathrm{Ce}^{3+}-\odot-\mathrm{Cu}^{+}$was converted to $\mathrm{Ce}^{4+}-\mathrm{O}^{2-}-\mathrm{Cu}^{2+}$ simultaneously. The strong oxidative ${ }^{\circ} \mathrm{OH}$ radicals oxidized phenol to produce $\mathrm{HQ}$ and CAT (Scheme 2C). Meanwhile, $\mathrm{Ce}^{4+}-\mathrm{O}^{2-}-\mathrm{Cu}^{2+}$ was

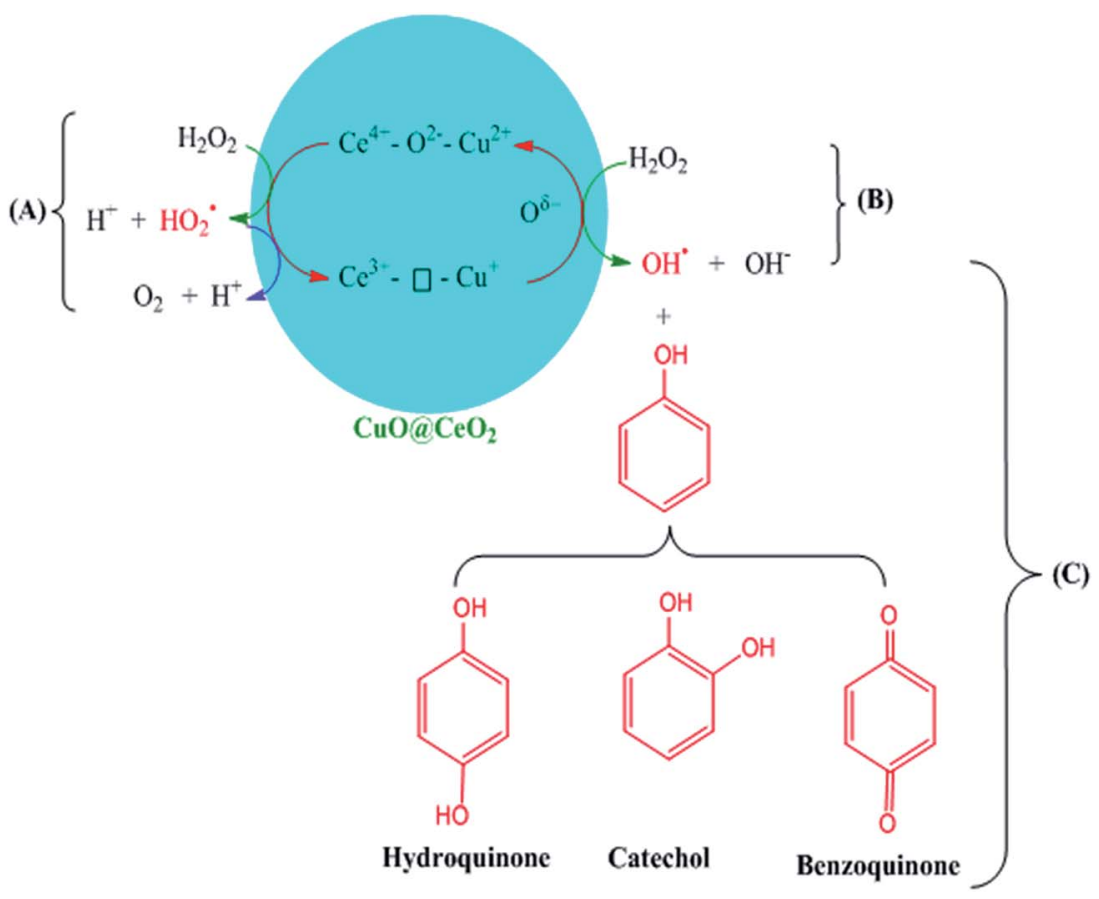

Scheme 2 Reaction mechanism in the presence of $\mathrm{CuOaCeO}-800{ }^{\circ} \mathrm{C}$.

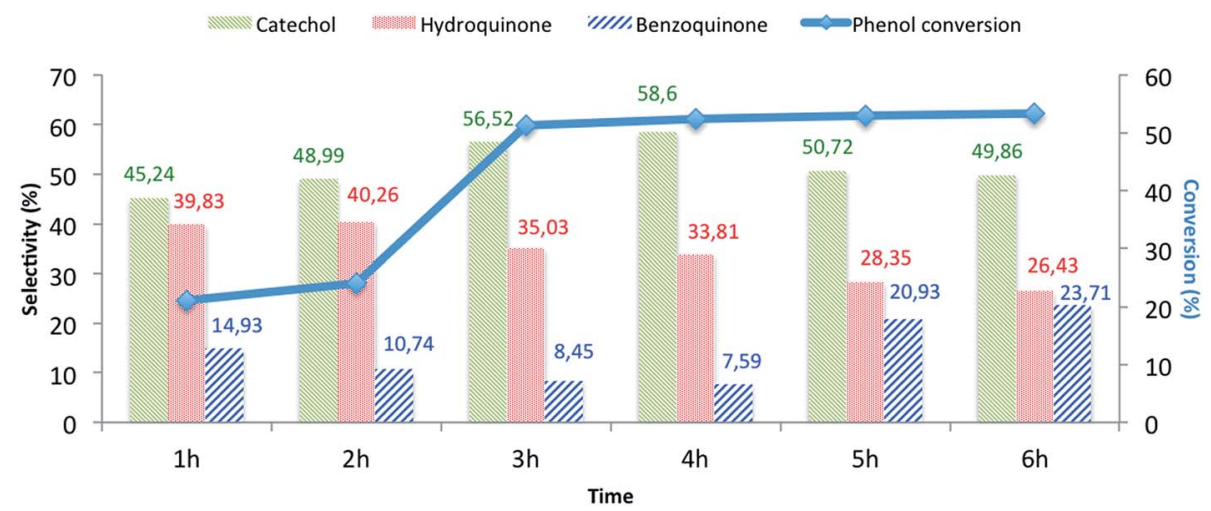

Fig. 9 Reuse performance of $\mathrm{CuO}\left(\mathrm{aCeO}_{2}-800{ }^{\circ} \mathrm{C}\right.$ catalyst ${ }^{\mathrm{a}}$. ${ }^{\mathrm{a}}$ Reaction conditions: phenol, $5 \mathrm{mmol} ; \mathrm{H}_{2} \mathrm{O}_{2}, 5 \mathrm{mmol}$; catalyst, $50 \mathrm{mg}$; water, $10 \mathrm{~mL}$; time, $3 \mathrm{~h} ; 80^{\circ} \mathrm{C}$. 

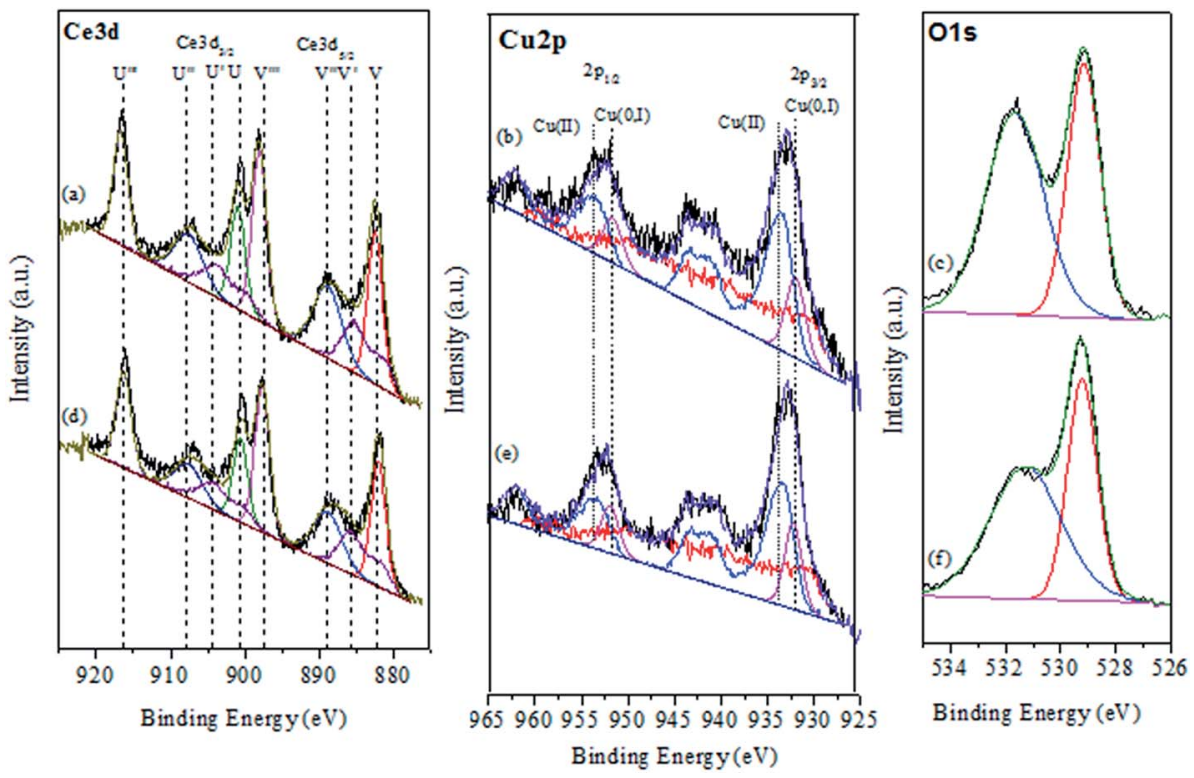

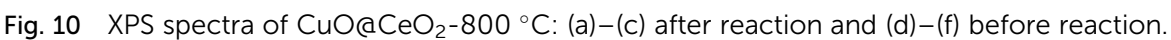

Table 8 Surface composition of $\mathrm{CuO}\left(\mathrm{CeO}_{2}-800{ }^{\circ} \mathrm{C}\right.$ before and after reaction determined by XPS

\begin{tabular}{lllll}
\hline & \multicolumn{4}{l}{ Surface element $(\%)$} \\
\cline { 2 - 5 } Samples & $\mathrm{Ce}^{3+}$ & $\mathrm{Ce}^{4+}$ & $\mathrm{Cu}^{2+}$ & $\mathrm{Cu}^{+}$ \\
\hline Before reaction & 20 & 80 & 62.71 & 37.29 \\
After reaction & 20 & 80 & 63.78 & 36.22
\end{tabular}

regenerated into the catalytic active $\mathrm{Ce}^{3+}-\odot-\mathrm{Cu}^{+}$through a formation of oxygen vacancies, which is being beneficial for the production and stability of the $\mathrm{Cu}^{+}{ }^{57} \mathrm{~A}$ side reaction (Scheme 2A) might occur along with the hydroxylation of phenol, where $\mathrm{Ce}^{4+}-\mathrm{O}^{2-}-\mathrm{Cu}^{2+}$ reacted with $\mathrm{H}_{2} \mathrm{O}_{2}$ to produce $\mathrm{O}_{2}$, leading to less utilization efficiency of $\mathrm{H}_{2} \mathrm{O}_{2} \cdot{ }^{51,56}$

Catalyst stability, heterogeneity and leaching are the most important criteria to evaluate the sustainability of any catalytic system. After completion of the first reaction, the ${\mathrm{CuO} @ \mathrm{CeO}_{2}^{-}}^{-}$
$800{ }^{\circ} \mathrm{C}$ catalyst was recovered by centrifugation and washed sequentially with water and dichloromethane and finally dried under vacuum over night. Utilizing the used catalyst, the above test reaction was performed again under the same condition. As shown in Fig. 9, the reused catalyst showed only slight deactivation in its activity after five cycle, which might be caused by gradual poisoning of the catalyst and the blocking of the pores of the catalyst by tar formed in the reaction..$^{55,58}$

In order to clarify the behavior of $\mathrm{CuO} @ \mathrm{CeO}_{2}-800{ }^{\circ} \mathrm{C}$ after recycling experiments, we examined the oxidation state of the catalyst after one catalytic cycle using XPS analysis (Fig. 10). The obtained results revealed that the oxidation state of cerium $\mathrm{Ce}^{4+} / \mathrm{Ce}^{3+}$ and copper $\mathrm{Cu}^{2+} / \mathrm{Cu}^{+}$and their concentrations remain unchanged in comparison with XPS of fresh catalyst (Table 8). By cons, we note that there is a slight increase in the heart of $O$ 1s peak intensity of $\mathrm{CuO} @ \mathrm{CeO}_{2}-800{ }^{\circ} \mathrm{C}$ at about $531.5 \mathrm{eV}$. This increase may be due to the high concentration of oxygen adsorbed on the catalyst surface $\mathrm{CuO} @ \mathrm{CeO}_{2}-800{ }^{\circ} \mathrm{C}$ by hydroxyl groups formed during the hydroxylation process.

Table 9 Comparison of the phenol conversion over various copper-containing catalysts

\begin{tabular}{|c|c|c|c|c|c|c|}
\hline Catalyst & Solvent & Phenol : $\mathrm{H}_{2} \mathrm{O}_{2}$ ratio & Temp $\left({ }^{\circ} \mathrm{C}\right)$ & Time (min) & Conversion (\%) & Ref. \\
\hline $\mathrm{CuO} @ \mathrm{CeO}_{2}-800{ }^{\circ} \mathrm{C}$ & Water & 1 & 80 & 180 & 54.62 & This work \\
\hline CuAPO-11 & Water & 1 & 60 & 360 & 34.8 & 63 \\
\hline $\mathrm{CuFe}_{2} \mathrm{O}_{4}-\mathrm{RGO}_{20}$ & Water & 1 & 55 & 30 & 35.5 & 64 \\
\hline $\mathrm{CuCl}_{2}-\mathrm{H}_{4} \mathrm{SiW}_{12} \mathrm{O}_{40}$ & Water & 1 & 70 & 270 & 39 & 60 \\
\hline CuUSY & Water & 1 & 60 & 120 & $9^{a}$ & 61 \\
\hline CuH B & Water & 1 & 60 & 120 & $35^{a}$ & 61 \\
\hline$[\mathrm{Cu}$-Imace-H $]\left[\mathrm{NO}_{3}\right]$ & Water & 1 & 70 & 180 & 27 & 59 \\
\hline $\mathrm{LaCuO}_{4}$ & Water & 1 & 70 & 120 & 50.9 & 62 \\
\hline $\mathrm{LaSrCuO}_{4}$ & Water & 1 & 70 & 120 & 2.2 & 62 \\
\hline $\mathrm{CuO}$ & Water & 1 & 70 & 120 & 11.7 & 62 \\
\hline
\end{tabular}

${ }^{a}$ Tars formation. 
To investigate the heterogeneity of the catalyst and the metal leaching, the hydroxylation reaction of phenol was maintained for $1 \mathrm{~h}$ in the presence of $\mathrm{CuO} @ \mathrm{CeO}_{2}-800{ }^{\circ} \mathrm{C}$ catalyst. After that, the catalyst was filtered and the filtrate obtained is stirred for additional $2 \mathrm{~h}$ at $80{ }^{\circ} \mathrm{C}$, the portion containing the catalyst showed $22 \%$ of phenol conversion, while the catalyst-free portion showed no product, evidently proving the heterogeneity of the catalyst. Metal leaching was studied by ICP-AES analysis of the catalyst before and after the reaction. The copper concentration of the catalyst was found to $4.6 \%$ for fresh catalyst and $4.4 \%$ after one catalytic cycle in phenol hydroxylation, which confirms negligible copper leaching. The catalytic activity of $\mathrm{CuO} @ \mathrm{CeO}-$ $800{ }^{\circ} \mathrm{C}$ catalyst was compared with reported homogeneous and heterogeneous copper-containing catalysts for phenol hydroxylation (Table 9). Indeed, our catalytic system exhibited higher catalytic activity in terms of phenol conversion. ${ }^{59-64}$

\section{Conclusion}

In summary, in this work, the objective is to explore new routes to optimize the synthesis of $\mathrm{CuO} @ \mathrm{CeO}_{2}$ catalysts using the surfactant-template method. The calcination temperature seems to affect significantly the crystallite size, surface area, degree of dispersion of $\mathrm{CuO} @ \mathrm{CeO}_{2}$ species and their catalytic activity for phenol hydroxylation. In particular, $\mathrm{CuO} @ \mathrm{CeO}_{2}$ when it is calcined at $800{ }^{\circ} \mathrm{C}$ showed the highest phenol conversion and selectivity for HQ and CAT, which was ascribed to the higher electronic exchange between the two redox pairs $\mathrm{Cu}^{+} / \mathrm{Cu}^{2+}$ and $\mathrm{Ce}^{3+} / \mathrm{Ce}^{4+}$, and the lattice oxygen provided by $\mathrm{Cu}-$ $\mathrm{O}-\mathrm{Ce}$ solid solution in $\mathrm{CuO} @ \mathrm{CeO}_{2}$ catalyst. Thereafter, the optimal reaction conditions were explored, and water was proved to be the optimum solvent of the reaction, which is environmentally friendly. The $\mathrm{CuO} @ \mathrm{CeO}_{2}-800{ }^{\circ} \mathrm{C}$ catalyst exhibited good catalytic stability and selectivity on phenol hydroxylation. Additionally, our catalytic system exhibited higher catalytic activity in terms of phenol conversion compared to copper-containing catalysts reported in the literature. The decrease in the catalytic activity of $\mathrm{CuO} @ \mathrm{CeO}_{2}-800{ }^{\circ} \mathrm{C}$ can be explained by a catalyst poisoning by tar, which is formed in situ during the reaction and get stuck on the catalyst surface even after washing.

\section{Acknowledgements}

We thank MAScIR Foundation for funding and support. We acknowledge also the financial assistance of the CNRST.

\section{Notes and references}

1 L. Krumenacker, M. Constantini, P. Pontal and J. P. Sentenac, Kirk-Othmer Encyclopedia of Chemical Technology, ed. J. I. Kroschwitz and M. Howe-Grant, Wiley, New York, 4th edn, 1995, vol. 13, p. 996.

2 K. Tennakone, G. R. R. A. Kumara, A. R. Kumarasinghe, P. M. Sirimanne and K. G. U. Wijayantha, J. Photochem. Photobiol., A, 1996, 94, 217-220.

3 P. Minosci and F. Maggioni, Chim. Ind., 1977, 59, 239.
4 J. Varagnat, Ind. Eng. Chem. Prod. Res. Dev., 1976, 15, 212215.

5 A. Dubey, J. Mol. Catal. A: Chem., 2002, 181, 151-160.

6 A. Dubey, S. Kannan, S. Velu and K. Suzuki, Appl. Catal., A, 2003, 238, 319-326.

7 E. A. Karakhanov, A. L. Maximov, Y. S. Kardasheva, V. A. Skorkin, S. V. Kardashev, V. V. Predeina, M. Y. Talanova, E. Lurie-Luke, J. A. Seeley and S. L. Cron, Appl. Catal., A, 2010, 385, 62-72.

8 Y. Zuo, W. Song, C. Dai, Y. He, M. Wang and X. Wang, Appl. Catal., A, 2013, 453, 272-279.

9 B. Wang, M. Lin, B. Zhu, X. Peng, G. Xu and X. Shu, Catal. Commun., 2016, 75, 69-73.

10 L. Gou and C. J. Murphy, Chem. Commun., 2005, 5907-5909. 11 Y. Jiang, K. Lin, Y. Zhang, J. Liu, G. Li, J. Sun and X. Xu, Appl. Catal., A, 2012, 445-446, 172-179.

12 T. Zhou, X. Lu, T.-T. Lim, Y. Li and F.-S. Wong, Chem. Eng. J., 2010, 156, 347-352.

13 T. Zhou, Y. Li, F.-S. Wong and X. Lu, Ultrason. Sonochem., 2008, 15, 782-790.

14 H.-S. Son, J.-K. Im and K.-D. Zoh, Water Res., 2009, 43, 14571463.

15 O. Amadine, H. Maati, K. Abdelouhadi, A. Fihri, S. El Kazzouli, C. Len, A. El Bouari and A. Solhy, J. Mol. Catal. A: Chem., 2014, 395, 409-419.

16 S. Mandal, C. Santra, K. K. Bando, O. O. James, S. Maity, D. Mehta and B. Chowdhury, J. Mol. Catal. A: Chem., 2013, 378, 47-56.

17 R. K. P. Purushothaman, J. van Haveren, D. S. van Es, I. Melián-Cabrera, J. D. Meeldijk and H. J. Heeres, Appl. Catal., B, 2014, 147, 92-100.

18 P. Lakshmanan, P. P. Upare, N.-T. Le, Y. K. Hwang, D. W. Hwang, U.-H. Lee, H. R. Kim and J.-S. Chang, Appl. Catal., A, 2013, 468, 260-268.

19 P.-O. Larsson and A. Andersson, Appl. Catal., B, 2000, 24, 175-192.

20 S. Scirè, C. Crisafulli, P. M. Riccobene, G. Patanè and A. Pistone, Appl. Catal., A, 2012, 417-418, 66-75.

21 P. Bazin, O. Saur, O. Marie, M. Daturi, J. C. Lavalley, A. M. Le Govic, V. Harlé and G. Blanchard, Appl. Catal., B, 2012, 119120, 207-216.

22 S. Sun, D. Mao and J. Yu, J. Rare Earths, 2015, 33, 1268-1274. 23 Q. Zhang, L. Xu, P. Ning, J. Gu and Q. Guan, Appl. Surf. Sci., 2014, 317, 955-961.

24 J. A. Rodriguez, S. Ma, P. Liu, J. Hrbek, J. Evans and M. Pérez, Science, 2007, 318, 1757-1760.

25 M. Manzoli, R. Di Monte, F. Boccuzzi, S. Coluccia and J. Kašpar, Appl. Catal., B, 2005, 61, 192-205.

26 M. Turco, C. Cammarano, G. Bagnasco, E. Moretti, L. Storaro, A. Talon and M. Lenarda, Appl. Catal., B, 2009, 91, 101-107.

27 F. Mariño, C. Descorme and D. Duprez, Appl. Catal., B, 2005, 58, 175-183.

28 E. P. Barrett, L. G. Joyner and P. P. Halenda, J. Am. Chem. Soc., 1951, 73, 373-380. 
29 A. Martínez-Arias, M. Fernández-García, O. Gálvez, J. M. Coronado, J. A. Anderson, J. C. Conesa, J. Soria and G. Munuera, J. Catal., 2000, 195, 207-216.

30 G. Avgouropoulos and T. Ioannides, Appl. Catal., A, 2003, 244, 155-167.

31 B. Flageolet, P. Villechaise, M. Jouiad and J. Mendez, Superalloys 2004, Proc. Int. Symp., 10th, 2004, 371-379.

32 R. Dziembaj, M. Molenda, L. Chmielarz, M. Drozdek, M. M. Zaitz, B. Dudek, A. Rafalska-Łasocha and Z. Piwowarska, Catal. Lett., 2010, 135, 68-75.

33 R. Si, J. Raitano, N. Yi, L. Zhang, S.-W. Chan and M. FlytzaniStephanopoulos, Catal. Today, 2012, 180, 68-80.

34 X. Wang, J. A. Rodriguez, J. C. Hanson, D. Gamarra, A. Martínez-Arias and M. Fernandez-García, J. Phys. Chem. B, 2005, 109, 19595-19603.

35 P. Bera, K. R. Priolkar, P. R. Sarode, M. S. Hegde, S. Emura, R. Kumashiro and N. P. Lalla, Chem. Mater., 2002, 14, 35913601.

36 M. L. Dos Santos, R. C. Lima, C. S. Riccardi, R. L. Tranquilin, P. R. Bueno, J. A. Varela and E. Longo, Mater. Lett., 2008, 62, 4509-4511.

37 M. Zawadzki, J. Alloys Compd., 2008, 454, 347-351.

38 D. Andreescu, E. Matijević and D. V. Goia, Colloids Surf., A, 2006, 291, 93-100.

39 T. Wang and D. C. Sun, Mater. Res. Bull., 2008, 43, 17541760.

40 Y. Q. Song, Q. H. Yang, H. W. Zhang, L. Peng and L. R. Shah, J. Phys.: Conf. Ser., 2009, 152, 012038.

41 H. Gu and M. D. Soucek, Chem. Mater., 2007, 19, 1103-1110.

42 L. Qi, Q. Yu, Y. Dai, C. Tang, L. Liu, H. Zhang, F. Gao, L. Dong and Y. Chen, Appl. Catal., B, 2012, 119-120, 308-320.

43 S.-P. Wang, X.-Y. Wang, J. Huang, S.-M. Zhang, S.-R. Wang and S.-H. Wu, Catal. Commun., 2007, 8, 231-236.

44 Y. Li, Y. Cai, X. Xing, N. Chen, D. Deng and Y. Wang, Anal. Methods, 2015, 7, 3238-3245.

45 P. Sudarsanam, B. Mallesham, D. N. Durgasri and B. M. Reddy, $R S C A d v$. , 2014, 4, 11322-11330.
46 S. Gregg, Adsorption, surface area, and porosity, Academic Press, London, New York, 1982.

47 K. S. W. Sing, Pure Appl. Chem., 1985, 57, 603-619.

48 P. Bera, S. Mitra, S. Sampath and M. S. Hegde, Chem. Commun., 2001, 927-928.

49 S. Zeng, Y. Wang, S. Ding, J. J. H. B. Sattler, E. Borodina, L. Zhang, B. M. Weckhuysen and H. Su, J. Power Sources, 2014, 256, 301-311.

50 L. Zhang, T. Chen, S. Zeng and H. Su, J. Environ. Chem. Eng., 2016, 4, 2785-2794.

51 C. Liu, Z. Zhao, X. Yang, X. Ye and Y. Wu, Chem. Commun., 1996, 1019-1020.

52 J. S. Reddy, S. Sivasanker and P. Ratnasamy, J. Mol. Catal., 1992, 71, 373-381.

53 J. Guo and M. Al-Dahhan, Ind. Eng. Chem. Res., 2003, 42, 2450-2460.

54 X. Liang, R. Yang, G. Li and C. Hu, Microporous Mesoporous Mater., 2013, 182, 62-72.

55 H. Tang, Y. Ren, B. Yue, S. Yan and H. He, J. Mol. Catal. A: Chem., 2006, 260, 121-127.

56 F.-S. Xiao, J. Sun, X. Meng, R. Yu, H. Yuan, J. Xu, T. Song, D. Jiang and R. Xu, J. Catal., 2001, 199, 273-281.

57 P. Zhu, M. Liu and R. Zhou, Indian J. Chem., Sect. A: Inorg., Bio-inorg., Phys., Theor. Anal. Chem., 2012, 51, 1529-1537.

58 R. Yu, F.-S. Xiao, D. Wang, J. Sun, Y. Liu, G. Pang, S. Feng, S. Qiu, R. Xu and C. Fang, Catal. Today, 1999, 51, 39-46.

59 H. Zhang, X. Zhang, Y. Ding, L. Yan, T. Ren and J. Suo, New J. Chem., 2002, 26, 376-377.

60 G. Yang, X. Hu, Y. Wu, C. Liu and Z. Zhang, Catal. Commun., 2012, 26, 132-135.

61 J. Wang, J.-N. Park, H.-C. Jeong, K.-S. Choi, X.-Y. Wei, S.-I. Hong and C. W. Lee, Energy Fuels, 2004, 18, 470-476.

62 C. Liu, Z. Zhao, X. Yang, X. Ye and Y. Wu, Chem. Commun., 1996, 1019.

63 Q. Xingyi, Z. Lili, X. Wenhua, J. Tianhao and L. Rongguang, Appl. Catal., A, 2004, 276, 89-94.

64 Y. Zhao, G. He, W. Dai and H. Chen, Ind. Eng. Chem. Res., 2014, 53, 12566-12574. 